\title{
Determinants of Poverty in Somalia: A Logit Model Analysis
}

\section{Abdiweli Mohamed MOHAMOUD ${ }^{1}$, Erol BULUT ${ }^{2}$}

Somali'de Yoksulluğun Belirleyicileri: Bir Logit Model Analizi

\section{ARTICLE INFO}

Article History:

Date Submitted:29.03.2020

Date Accepted: 20.04.2020

JEL Classification:

I32,

I38,

J11.

Keywords:

Poverty,

Households,

Logit Model

\section{ABSTRACT}

The main purpose of this study is to identify the key factors that determine a household's poverty status. The study uses an econometric method, which called "logistic regression" analysis to determine the probability of a household being poor. The data used in the study is obtained from Somali High-Frequency Survey (SHFS) Wave II conducted by World Bank in collaboration with Somali statistical authorities in December 2017. The study found that type of residence household size, household head education, the share of literate in the household, access to electricity and small family business, agriculture fishing and hunting significantly explain the variation in the likelihood of being poor. Share of males in the household and agriculture, fishing and hunting as the main source of income for households reduces the probability of being poor. The study does not found a strong relationship between the probability of being the poor and the educational level of the household head.

\footnotetext{
${ }^{1}$ Department of Economics, Ankara HBV University, Turkey; e-mail: abdiwelicdde@gmail.com

${ }^{2}$ Department of Economics, Ankara HBV University, Turkey; e-mail: erol.bulut@ hbv.edu.tr
} 


\section{Özet}

Bu çalışmanın temel amacı, bir hanenin yoksulluk durumunu belirleyen temel faktörleri belirlemektir. Çalışmada, bir ailenin yoksul olma olasılığını belirlemek için "lojistik regresyon" analizi adı verilen ekonometrik bir yöntem kullanılmıştır. Araştırmada kullanılan veriler, Aralık 2017'de Dünya Bankası tarafından Somali istatistik yetkilileri ile işbirliği içinde yürütülen Somali Yüksek Frekans Araştırması (SHFS) Wave II'den elde edilmiştir. Çalışma, konut tipi hanehalkı büyüklügü, hanehalkı başı eğitimi, hanehalkı okuryazarlığı, elektriğe ve küçük aile işletmelerine erişim, tarımda balıkçılık ve avcılık, yoksul olma olasılığındaki değişimi önemli ölçüde açıklamaktadır. Hanelerin ana gelir kaynağı olan tarım, balıkçılık ve avcılıktaki erkeklerin oranı, yoksul olma olasılığını azaltmaktadır. Çalışma, yoksul olma olasılığı ile hanehalkı reisinin eğitim düzeyi arasında güçlü bir ilişki bulmamıştır.

\section{Anahtar Kelimeler: Fakirlik, Hanehalkı, Logit Modeli}

\section{Introduction}

Poverty is a contested concept and there are certain reasons for this. Debates on how to conceptualize, define and measure poverty are phenomena that extend beyond semantics and academic researches. For a long time in history, poverty has been seen as an individual or social problem (Alcock, 1997: 20-25). The phenomena of poverty become so technical and it is difficult to draw a conclusion of how we define it. The important factor in the definition of poverty is that the definition implies policy. The way poverty is defined and measured tends to determine the type and aspects of policies aimed at reducing poverty. Assessing the causes of poverty and shaping strategies to reduce it is central to the definition of poverty. Recognizing the problem of poverty allows the appreciation of the difficulties and serves as a reminder that looks for strategies and draws on the body of knowledge accumulated in the field of development studies. Understanding poverty facilitates adopting an effective redistribution policy for poverty alleviation (Sekhampu, 2013: 145-153).

The earliest definitions of poverty centered on the inability to obtain adequate food and other basic necessities. Today, the main focus continues to be on material deprivations, i.e., the failure to command private resources. Development experts have argued that this notion of 
economic welfare remains too narrow to reflect individual well-being, spurring active efforts over the past several decades to expand the concept of poverty. As the approaches to poverty change, the considerations on to what extent it affects all the countries also change. For example, it is said that the poverty is so harsh in the developing and underdeveloped nations, but that is also the case for the developed countries. Norway, a developed country, especially the natives, maybe is not affected from the poverty directly, but as for the immigrants, it is quite different Like the changes in the attributes to poverty, the poverty can be analyzed under two categories. As a matter of fact there are two types of poverty namely absolute and relative poverties. "Absolute poverty" is the absolute level of poverty in which the people do not even support their basic needs and in which the resources of the people are even below the level of threshold experiences. However, on the other hand, relative poverty is depended on a comparison, the comparison of one's situation with the others, or with the past. This means that in this type of poverty, the poverty is relative and it is changeable from person to person, from country to country, and so on. Relative poverty is much more informative than the absolute poverty because the poverty experiences of the poor people are more affected from by the affluence in a more culturally broader context than their real level of deprivations (Barusch, 2009: 140).

In the recent past, many countries adopted policies and visions against poverty which has recognized as an incurable disease over the past years. The Millennium development goals (MDGs) was failed for halving the world's poverty in 2015 and not achieved to mention the poverty reduction papers and structural adjustment programs designed for developing countries. The failure of Millennium Development Goals has brought up the concept of sustainable development policies which is not yet predicted its success. The phenomena of poverty affect all countries around the globe. According to Gregory and Sheehon (1998) identified unemployment as a major cause of income poverty. As indicated by Angaye, (2005), poverty is an incurable disease and engulfing more of the world's population. The number of people engulfed by poverty in the world stood at 1 billion people in 1994, 1.3 billion in 1995 and 2.56 billion in 2002, and the figure has to increase unless all governments and Non-governmental organizations (NGOs) put an effort to alleviate poverty. According to Olu (2003) indicated that poverty in developing countries has substantially increased over the past years in terms of the low level of nutrition, low level of education, declining government's spending on social 
services, higher spending on food consumption by households, low level of saving, insufficient of infrastructure and so on.

In Somalia, the civil war and continuing conflicts since 1991 disintegrated the country, destroyed political institutions and led to human vulnerability. Due to the ongoing conflict, statistical infrastructure had been eroded; leaving policymakers and donors to work in a statistical vacuum due to the lack of reliable data and it is difficult to know more about poverty in the situation of the absence of representative household surveys. In the absence of household data, information poses a risk to design and develop policies needed to help economically vulnerable people in the event of shocks. In 2002 the socioeconomic survey carried out with support from the United Nations and Development program (UNDP) and the World Bank gives the nationally representative data on Somalia. the survey indicated 43 percent of the total population were estimated living utmost poverty based on US\$1 per day in Purchasing power parity (PPP), and the survey also estimated 73 percent of the population was living on less than $\$ 2$ per day. The percentage population living on less than a dollar a day was $24 \%$ in far urban areas climbing up to $53 \%$ in rural areas and nomadic areas. Despite this survey, there have been dynamic changes that had taken since this survey was carried out, these figures are not considered to be representative of the current situation of poverty in Somalia. Due to the lack of updated data for the current level of poverty in Somalia, the World Bank carried out a substantial survey in 2016. According to that survey, poverty is widespread in Somalia and defined poverty living a total consumption less than the international poverty line of $\$ 1.90$ in 2011 purchasing power parity (PPP), and also varies among the Somali population. The study also indicated the existence of regional difference in the percentage of the population living in poverty, for example, North East (27 percent) and North West (50 percent) and urban areas poverty range from 26 percent in North East to 57 percent in the capital city (Mogadishu). And also poverty in rural areas ranges from 34 percent in North East (NE) to 61 percent in North West (NW). The study also indicated poverty incidence is higher in IDPs settlements where 70 percent are poor, where roughly 9 percent of Somalis populations are considered internally displaced people.

This study aimed to analyze the key determinants of poverty in Somalia, the study specifically was focused on the contribution made by household variables such as sex of 
household head, age of household head, number of children in the household, source of income of the household and others variables listed in the model applied. In the second chapter of the study the relevant literature is reviewed. Methodology and source of data are presented in the third chapter of the paper. Results and discussions are presented in the fourth section and the fifth section which is the last section summarizes concludes and recommends adequate conclusions from the study.

\section{Literature Review}

Many theories explain the existence of poverty in less developed countries. The theories examined in this study are individual deficiency theory of poverty, the natural circumstantial theory of poverty and theories that lay the cause on broader social and economic phenomena.

The theory of individual deficiency of poverty is a wider multifaceted set of concepts that focuses on the individuals as the primary responsibility of their poverty situations. Many theoreticians blame individuals in poverty are those responsible for their poverty situation and argue that harder work is the only way to avoid being poor. Some other theoreticians argue poverty as a result of a lack of genetic qualities such as intelligence of the individuals that are difficult to reverse (Akeredolu-Ale, 1975: 66-68). Neo-classical economics supports that individuals are responsible for their poverty situation. The study for the conditions leading to poverty is that individuals seek to maximize their well-being by taking decisions and seek to maximize their wellbeing. If a person chooses to work short and get low payoff returns, that person is responsible for their personal choices (for example, to go and get a college education or training that will help for the future to get better-paying jobs).

The natural circumstantial theory of poverty describes some geographical locations, age, natural disasters, inadequate natural resource endowment, mental and physical disabilities, and some others are the key primary explanatory variables for the existence of poor people in some areas of the world. The Anti-poverty programs that the theory suggests to eradicate poverty are sectional welfare measures that must be provided to poor people such as access to health care, electricity and pipe water. Even though Anti-poverty suggestions of this theory are regarded as very important as a poverty eradication measure, some developing countries failed to adopt an 
effective policy against poverty. In the case of Somalia, several successive seasons of rainfall shortage led to severe drought on Somalia, as studies show 50 percent of Somalis faced intense food insecurity and around 1 million Somalis displaced in 2017. Between April 2016 and December 2017 due to the four consecutive rainfall shortages below-average rainy seasons resulted in severe drought. The drought severely affected Somalis in rural areas, who were more like to be poor. Due to the drought, rural household consumption declined and increased their probability of poor people being poor (World Bank, 2019: 22-34).

The different theories of poverty address individuals, their culture, the social and economic structure in which they are embedded, places of residence, and the interconnections among the different variables that propose different theories of poverty from different perspectives. Due to the complexity of the causes of poverty led to multiple views of perspectives.

From an empirical point of view, there have been various studies (e.g. Geda et al. (2004) for Kenya; Amuedo-Dorantes (2004) for Chile; Glewwe, (1991) for Cote d' Ivoire) that explain factors that determine one's poverty status. These studies focus on key characteristics of the household as a whole or the characteristics of the household head (e.g. gender, years of schooling, occupation, age and so on) as possible determinants of poverty. Household-level data is useful for determining a household's poverty level. The most important determinants of household poverty are the gender of household head, age and educational level of the household's head. According to the study by Malik, (1996) concluded households whose household heads are in higher age groups are less of remaining poor. Additionally, the level of household education also significantly reduces the chance of remaining poor (Minot \& Baulch, 2005). Households headed by males are found to have a lower probability of being poor (Geda et al.2004). Malik (1996) and Minot \& Baunch (2005) found dependent ratio and family size are positively related to the level of poverty. Also, the other factors that contribute to the poverty level are gender and the occupation of the household head.

Brück, Danzer, Muravyev, \& Weisshaar, (2010) conducted a study of the severity and key determinants of household poverty in Ukraine. The study found poverty existed even among households who have a job. They used the income-consumption method to measure 
poverty. the variable that they explained as a determinant of poverty were income, level of education, inequality in government spending and high level of prices. Oyugi (2000) applied a probit model by using Kenyan Welfare Monitoring survey data in 1994. The explanatory variables of the study included: livestock unit, landholding area, the literacy rate in the household members, household size, economic activity (Agriculture, industry, etc.) and source of water. The analysis of the model show all the explanatory variables used was significant determinants of poverty in rural areas at a national level, but the study except for urban areas. According to the study by Muhammedhussen(2015) using the logistic regression model analyzed determinants of rural income poverty in Ethiopia. The study found that family size is positively associated with household poverty and the study also found the household's main source of income, farmland ownership, and livestock ownership was negatively related to poverty status.

\section{Methodology}

The research methodology we used in the study explained in the following subsections, section one was data and its source and the second section of this part was about the adopted model and data analysis.

\subsection{Data}

The data used in the study was obtained from the second wave of the Somalia Highfrequency survey (SHFS) conducted by the World Bank in collaboration with Somali statistical authorities in December 2017 to monitor welfare and perceptions of Somalis in all 17 regions. The survey participated by 4,011 urban households, 468 households in IDPs (Internally displaced persons) settlements, 1,106 rural households, and 507 nomadic households. The dataset comprises pieces of information on the economic and social conditions of households.

\subsection{Logistic Regression Model}

The study adopted a logistic regression model with two dependent variables of dichotomous nature. The founder of the logistic regression model was Cox, (1958); afterward, Walker and Duncan, (1967) developed his model, and later Cox himself (1970). More recently, 
the model has further developed by Lee (1980) and Fox (1985). Based on the household's income, households are classified as either poor or non-poor. The explanatory variables of the model are a set of variables that shows the socioeconomic status of the households. The equational form of the model are explained below:

$$
Y_{i}=F\left(X_{1 i}, X_{2 i}, \ldots \ldots \ldots X_{k i}\right)
$$

$Y_{i}$ stands for households' poverty status and $X s$ representing the various explanatory variables that determine the socioeconomic status of the households. suppose that the dependent variable $(y)$ captures the true status of the households as either poor or non-poor, the regression equation can be estimated as follows;

$$
Y_{i}^{*}=\sum_{J=0}^{K} X_{i j} \beta_{j}+\varepsilon_{i}
$$

According to the above equation, $\mathrm{y}^{*}$ is latent variables (hidden variables) and $X$ is a dummy variable that takes the value of 1 or 0 otherwise. The $\varepsilon$ denotes the error term and calls for the common assumption of zero mean but the underlying distribution is different.

Suppose $\mathrm{P}_{\mathrm{i}}$ represents the probability that $i^{\text {th }}$ household income is below the poverty line and its distribution is determined by the vector of predictors $\mathrm{X}$, so that;

$$
\mathrm{P}_{i}(\mathrm{X})=\frac{e^{\beta \mathrm{X}}}{1+e^{\beta \mathrm{X}}}
$$

Where $\beta$ stands for a row vector, finally the logit model is then written as;

$$
\operatorname{Logit}(p)=\ln \left(\frac{p}{1-p}\right)=\sum_{J=1}^{K} X_{i j} \beta_{j}+\varepsilon_{i}
$$

The dependent variables in the model assumed to truly capture the welfare status of households. 
Table: 1: List of the Variables in the Equation

\begin{tabular}{|l|l|}
\hline Dependent Variable & $\begin{array}{l}\text { POV= Household Income measured on PPP } 2011 \text { poverty Line } \\
(0=\text { non-poor, 1= poor })\end{array}$ \\
\hline \multicolumn{2}{|c|}{ Explanatory Variables } \\
\hline Type of Residence & Main Source of Household Income \\
- Urban & - Salaried Labor \\
- Rural & - Remittance** \\
- IDPs & - Small Family Business \\
- Nomads & - Agriculture, fishing, and Hunting \\
\hline Household Situation & Others \\
- Household Size & Household Head Education \\
- Number of Children in the HH & - Incomplete Primary \\
- Household Head Gender & - Complete Primary \\
- Household Head Age & - Completed Secondary \\
- Share of Males in HH & - Oniversity \\
\hline
\end{tabular}

Notes: * Internally displaced persons (IDPs), ${ }^{* *}$ Money sent back to home from abroad

\section{Empirical Results and Discussion}

According to the data analyzed, the study was examining the relationship between the dependent variable and a set of explanatory variables explaining the probability of a certain household being poor. The main purpose of the study was to identify the key socioeconomic factors that explain the poverty status of households and how these factors determine the risky of poverty status of households. Table 2 below shows the estimated coefficients from the Logistic Regression presented above and the dependent variable coded on if the household's income is below PPP 2011 poverty line, the positive coefficient indicates that the probability of a household being poor is high and vice versa. The explanatory variables in the category of the type of residence all significantly explain the poverty status of households except IDPs (internally displaced people). The negative sign of the estimated coefficients ( $\beta=-0.554$ for Rural households, $\beta=-0.008$ for IDPs households and $\beta=-0.707$ for Nomadic households) indicate the type of residence negatively affect the household's probability of being poor and all the variables are significant. The odd ratio reveals IDPs households had a higher chance of being poor than others. Internally displaced persons (IDPs) are people who displaced due to 
wars, droughts, and other drivers, these persons left behind everything they had and live camps in or near main cities and face many challenges because of the displacement, and this caused them to be more vulnerable.

The estimated coefficients of Household size $(\beta=0.396)$, Number of children's in the households $(\beta=-0.055)$, household head gender $(\beta=-0.154)$, household head age $(\beta=-0.004)$ and share of males in households $(\beta=-0.405)$ significantly determine the welfare status of households. The positive coefficient of household size indicates a positive relationship between household size and the probability of being poor, this means large households have a higher chance of being poor than small size families. Household head gender also determines poverty status of households, in Somalia, about 58 percent of households are headed by men and there is gender difference across regions, for example in Mogadishu (Banadir Region) 52 percent of household are more likely to be headed by women, 54 percent in IDPs settlements and 37 percent in a rural household. Similarly, the age of the household head is also another important determinant of household poverty status; it is found that families headed by old people are more likely to be poor. Share of males in the household, the estimated coefficient reveals a negative relationship; numbers of males in the household is important as males are more likely to participate in the labor market than women. Traditionally Somalia, women mostly do home jobs and care for the children and the men participate in the labor market.

Education allows people to have better economic opportunities and improve their welfare. In Somalia, men are more likely to get a formal education. Mostly the estimated coefficients regarding the educational level of the household head show a positive relationship with the welfare status of households. The result of the regression indicates completing a primary level of education is the significance and will contribute to a higher level of household welfare. The estimated coefficient for primary school completed household head $(\beta=0.324)$ shows a higher chance of being poor, the odds ratio indicates that the risk of being poor is higher. The estimated coefficient of share of literate members in the household $(\beta=-0.783)$ indicates a negative relationship share of literate household members and the probability of the welfare status of households and the relationship is significant. The international evidence indicates the educational outcome tends to be associated with poverty. Improving the educational level of the poor may allow them to engage in better income-generating economic 
activities and enhance their consumption levels. Similarly, household's access to electricity is also another important determinant of the welfare status of households. The estimated coefficient of share households with access to electricity $(\beta=-0.818)$ indicates a negative relationship and significance. Other important explanatory variables are the main source of livelihood for the households; agriculture, fishing, hunting, and small family business are found to be significant for explaining the likelihood of welfare status of households. In Somalia agricultural sector which comprises crop production, livestock, fishing, and hunting are the main source livelihood of more than half of the Somalis population. The estimated coefficients of livelihood sources indicate a negative relationship with the likelihood of households being poor. Similarly, the small family business is also found to be significant, as the private sector plays a significant role in the Somali economy, the small family business is regarded as the main source of livelihood for many small families. Although remittance plays a significant role in the Somali economy the study was not found to be significant in explaining the poverty status of households. 
Table: 2: Results of the Logistic Regression Analysis

\begin{tabular}{|c|c|c|c|c|c|c|c|}
\hline \multirow[t]{2}{*}{ Explanatory Variables } & \multirow[t]{2}{*}{$\boldsymbol{\beta}$} & \multirow[t]{2}{*}{ S.E } & \multirow[t]{2}{*}{ Wald } & \multirow[t]{2}{*}{$\mathbf{P}$} & \multirow{2}{*}{$\begin{array}{c}\text { Odd } \\
\text { Ratio }\end{array}$} & \multicolumn{2}{|c|}{$\begin{array}{c}95 \% \text { C.I. } \\
\text { for Odd ratio }\end{array}$} \\
\hline & & & & & & Lower & Upper \\
\hline Type of Residence & Reference & - & - & - & - & - & - \\
\hline Rural &,- 554 &, 118 & 22,077 & ,000 &, 574 & 456 &, 724 \\
\hline $\mathrm{IDP}^{*}$ &,- 008 &, 137 & ,003 & ,955 & ,992 & ,759 & 1,298 \\
\hline Nomads &,- 707 & 173 & 16,682 & ,000 & ,493 & 351 & 692 \\
\hline Household Size & ,396 & ,037 & 117,311 & 000 & 1,486 & 1,383 & 1,597 \\
\hline $\begin{array}{l}\text { Number of Children in } \\
\mathrm{HH}\end{array}$ &,- 068 &, 035 & 3,669 &, 055 & ,935 & 872 & 1,002 \\
\hline $\begin{array}{l}\text { Household Head } \\
\text { Gender }\end{array}$ & ,154 & ,079 & 3,830 &, 050 & 1,167 & 1,000 & 1,362 \\
\hline Household Head Age &,- 004 &, 004 & 1,355 & 244 & ,996 & ,989 & 1,003 \\
\hline Share of Males in $\mathrm{HH}$ &,- 405 & 209 & 3,743 & 053 & ,667 & ,442 & 1,005 \\
\hline $\begin{array}{c}\text { Household Head } \\
\text { Education }\end{array}$ & Reference & - & - & - & - & - & - \\
\hline Incomplete Primary &, 180 & 136 & 1,757 &, 185 & 1,197 & ,918 & 1,561 \\
\hline $\begin{array}{l}\text { Complete Primary } \\
\text { Incomplete Secondary }\end{array}$ &, 324 &, 143 & 5,154 & ,023 & 1,382 & 1,045 & 1,828 \\
\hline Complete Secondary & 195 &, 152 & 1,636 & 201 & 1,215 & ,902 & 1,638 \\
\hline University & 125 &, 106 & 1,371 & ,242 & 1,133 & ,919 & 1,396 \\
\hline Others &,- 285 & 277 & 1,058 & ,304 & ,752 & ,437 & 1,295 \\
\hline $\begin{array}{l}\text { Share of Literate in } \\
\mathrm{HH}\end{array}$ &,- 783 &, 117 & 44,688 &, 000 &, 457 & ,363 &, 575 \\
\hline $\begin{array}{l}\text { Share of Households } \\
\text { with Access to } \\
\text { Electricity }\end{array}$ &,- 818 &, 101 & 65,650 & ,000 & ,441 &, 362 &, 538 \\
\hline $\begin{array}{c}\text { Main Source of } \\
\text { Income }\end{array}$ & Reference & - & - & - & - & - & - \\
\hline Remittance $^{* *}$ &,- 073 & 157 & ,218 & ,641 & ,929 & ,683 & 1,264 \\
\hline Small Family Business &,- 206 & ,093 & 4,868 & 027 & 814 & ,678 & 977 \\
\hline $\begin{array}{l}\text { Agriculture,Fishing and } \\
\text { Hunting }\end{array}$ &,- 363 &, 138 & 6,896 & ,009 & ,696 &, 531 & ,912 \\
\hline Others &,- 014 &, 147 & 009 & ,923 & ,986 & ,738 & 1,316 \\
\hline Intercept & ,039 &, 210 & ,035 &, 853 & 1,040 & - & - \\
\hline
\end{tabular}

Source: Author's calculation using SPSS

Notes: " Internally displaced People, "* Money sent back to home from abroad 


\section{Conclusions and Policy Recommendations}

The main objective of this study was to find the key socioeconomic variables that determine the poverty status of households. The study used secondary data from Somali highfrequency survey (SHF) data carried out by World Bank in collaboration with Somali statistical authorities in December 2017. Based on the finding of the study, we may conclude that poverty is high in households live in IDPs camps and households with large household size, as well as, the households head are less educated, the household head is old, the share of males in the household is less, have a small family business and practice agriculture, fishing and hunting. Household lives in IDPs camps are found to be poorer than rural and nomadic households. The plausible reason might be IDPs residents displaced for drought and other prosecutions while nomadic people have strong assets which are livestock, e.g. camels (a strong animal which can survive without actually drinking water for 30 days), cows and goats.

Policy implications of the above findings are tremendous, especially for a poor country like Somalia where half of the population lives under poverty. Household size plays a significant role in determining the likelihood welfare status of households; the results show a positive relationship between the household size and the probability of being poor. This entails as the size of the household increases their likelihood of being also increases, so there is a strong need to raise public awareness for family planning. Knowing family planning has an impact on family size, which is a significant predictor of household poverty. The education level of the household head is also another significant predictor, household heads with less education have a higher probability of being poor than the household heads with higher levels of education. The result of the regression shows the share of literature persons in the household as a significant predictor and its probability is high. The plausible reason might be due to the high level of unemployment in the country; even those graduated from university cannot easily find a job. The share of households with access to electricity was negatively associated with the probability of being poor. Although there is a difference in access to electricity for different locations of households, the household share of access to electricity plays a significant role in explaining the welfare status of households. 
Agriculture, fishing, and hunting are the main sources of livelihood in Somalia, the findings of the study show agriculture, fishing and hunting negatively associated with the probability of being poor. In Somalia agriculture especially livestock production and hunting are common livelihood sources in the northern part of the country. Many nomadic households' lives depend on livestock and hunting. Similarly, crop production and fishing are the dominant sectors for livelihood in the southern part of the country. Based on its importance the study suggests protecting this sector may have a positive effect on welfare for households.

\section{References}

Akeredolu-Ale, E. O. (1975), "Poverty as a Social Issue: A Theoretical Note, in Poverty in Nigeria", Proceedings of the Annual Conference of the Nigerian Economic Society, (06), 66-68.

Alemayehu Geda and Niek de Jong, G. (2004), “Determinants of Poverty In Kenya: A Household Level Analysis", 1-27, https://media.economics.uconn.edu/working/2005-44.pdf, 20.02.2020,

Alcock, P. (1997), Understanding Poverty, London: Macmillan Press.

Amuedo-Dorantes, C. (2004), "Determinants and Poverty Implications of Informal Sector Work in Chile, Economic Development and Cultural Change, 52(2), 347-368, https://doi.org/10.1086/380926.

Angaye, G. S. (2005), "Poverty Amid Plenty in Nigeria Rivers", Journal of Social Sciences, V.5, 1-11.

Barusch, A.S. (2009), Foundations of Social Policy, Social Justice in Human Perspective, Third Edition, USA: Centage Learning Publication.

Brück, T., Danzer, A. M., Muravyev, A., and Weisshaar, N. (2010), "Poverty During a Transition: Household Survey Evidence from Ukraine", Journal of Comparative Economics, 38(2), 123-145, https://doi.org/10.1016/j.jce.2009.10.002.

Cox, D. R. (1958), “The Regression Analysis of Binary Sequences”, Journal of the Royal Statistical Society: Series B (Methodological), 20(2), 215-232, https://doi.org/10.1111/j.2517-6161.1958.tb00292.x.

Fox, J. (1985), Linear Statistical Models and Related Methods, New York: Wiley. 
Glewwe, P. (1991), "Investigating the Determinants of Household Welfare in Côte d'Ivoire", Journal of Development Economics, (Vol. 35), 23-37, https://doi.org/10.1016/03043878(91)90053-X

Gregory, R. G. and P. Sheehan (1998), 'Poverty and the Collapse of Full Employment', in R. Fincher and J. Niewenhuysen, (eds.), Australian Poverty: Then and Now, Melbourne University Press, Melbourne, 103-26.

Lee, E. T. (1980), Statistical Methods for Survival Data Analysis, Belmont, California: Lifetime Learning Publications (1709).

Malik, S. (1996), "Determinants of Rural Poverty in Pakistan a Micro-Study", Pakistan Development Review, 35(2), 171-187, https://doi.org/10.30541/v35i2pp.171-187.

Minot, N., and Baulch, B. (2005), "Poverty Mapping with Aggregate Census Data: What is the Loss in Precision?", Review of Development Economics, 9(1), 5-24, https://doi.org/10.1111/j.1467-9361.2005.00261.x.

Muhammedhussen, M. (2015), "Determinants of Rural Income Poverty in Ethiopia: Case Study of Villages in Dodola District", International Research Journal Publisher: Global Journals Inc, 15(11).

Oyugi, Lineth Nyaboke (2000), "The Determinants of Poverty in Kenya” (Unpublished MA Thesis, Department of Economics, University of Nairobi).

Sekhampu, T. J. (2013), "Determinants of Poverty in a South African Township", Journal of Social Sciences, 34(2), 145-153, https://doi.org/10.1080/09718923.2013.11893126.

Walker, S. H. and Duncan, D. B. (1967), "Estimation of the Probability of an Event as a Function of Several Independent Variables", Biometrika, 54(1), 167-179, https://doi.org/10.1093/biomet/54.1-2.167

World Bank (2019), "Somali Poverty and Vulnerability Assessment", World Bank Publications, <http://documents.worldbank.org/curated/en/464241565765065128/Findings-fromWave-2-of-the-Somali-High-Frequency-Survey>, 10.03.2020. 